\title{
Statism and Cosmopolitanism on Global Justice and Universal Fundamental Rights
}

\author{
Fabio Coacci \\ MGIMO University \\ 76 Prospekt Vernadskogo, Moscow, 119454, Russian Federation \\ University of Macerata (Italy) \\ 30/32 Via Giovanni Mario Crescimbeni, 62100, Macerata MC, Italy \\ f.coacci1@studenti.unimc.it
}

\begin{abstract}
This review paper critically assesses the two main theories of global justice, statism and cosmopolitanism, according to which fundamental rights, and their corresponding duties, ought to be differently upheld, and enforced, at the global level. Its main aim is to go beyond the limitations of these theories defending the equal relevance of both fundamental civil and political rights and socio-economic rights, and their corresponding duties, at the global level and the need for the assessment of their implementation according to the level of their justification. To pursue this objective, the paper argues for the conceptualization of a fair (common) mean among these two categories of rights which can be morally and politically constructed on the very basic right to reciprocal and general justification. Accordingly, the focus is posed on the interconnection as well as conflicts between these two categories of rights, and their corresponding duties, establishing a 'measure' according to which their justification can be assessed, and their implementation and enforcement be ensured. This paper seeks also to prove that this conceptualization of fundamental rights and duties, which takes together Aristotle's conception of justice and Forst's critical theory of political and social justice, can provide a sketch on how a fair implementation and enforcement of peoples' and persons' rights and duties ought to be conceived at the global level.
\end{abstract}

Keywords: statism, cosmopolitanism, global justice, fundamental universal rights, distribution of rights and duties, civil and political rights, socio-economic rights, fair mean, Aristotle's conception of justice

Article history: Submitted on 30.03.2020. Accepted on 10.05.2020.

For citation: Fabio Coacci. Statism and Cosmopolitanism on Global Justice and Universal Fundamental Rights. RUDN Journal of Political Science. 2020; 22 (3): 352-366. DOI: 10.22363/23131438-2020-22-3-352-366

(C) Coacci F., 2020.

This work is licensed under a Creative Commons Attribution 4.0 International License https://creativecommons.org/licenses/by/4.0/ 


\title{
Глобальная справедливость и универсальные основные права человека с точки зрения этатизма и космополитизма
}

\author{
Фабио Коаччи \\ Московский государственный институт международных отношений (университет) \\ Министерства иностранных дел Российской Федерации \\ Российская Федерачия, 111395, Москва, Проспект Вернадского, 76 \\ Университет Мачерата (Италия) \\ Италия, 62100, Мачерата, Виа Джованни Марио Крешимбени, 30/32 \\ f.coacci1@studenti.unimc.it
}

\begin{abstract}
Аннотация. В данной обзорной статье критически оцениваются две основные теории глобальной справедливости, этатизм и космополитизм, согласно которым основные права человека и соответствующие им обязанности должны по-разному обеспечиваться и применяться на глобальном уровне. Основная цель - выйти за рамки ограничений этих теорий, отстаивая равное значение как основных гражданских и политических прав, так и социальноэкономических прав и соответствующих им обязанностей на глобальном уровне, а также необходимость оценки их реализации в соответствии с уровнем их оправдания. Для достижения этой цели в статье предлагается концептуализация справедливого (общего) среднего значения для этих двух категорий прав, которое с моральной и политической точек зрения может быть основано на самом базовом праве на взаимную и общую справедливость. Соответственно, основное внимание уделяется взаимосвязи, а также противоречиям между этими двумя категориями прав и их соответствующими обязанностями, устанавливая «меру», в соответствии с которой может быть оправдано их право на существование, а также обеспечена их реализация и применение. Автор также стремится показать, что предлагаемая им концептуализация основных прав и обязанностей, объединяющая в себе концепцию справедливости Аристотеля и критическую теорию политической и социальной справедливости Форста, может дать представление о том, как справедливое осуществление и защита прав человека и соответствующие обязанности должны рассматриваться применительно к глобальному уровню.
\end{abstract}

Ключевые слова: этатизм, космополитизм, глобальная справедливость, основные универсальные права, распределение прав и обязанностей, гражданские и политические права, социально-экономические права, справедливое среднее, аристотелевская концепция справедливости

История статьи: Поступила в редакцию 30.03.2020. Принята к публикации 10.05.2020.

Для цитирования: Coacci F. Statism and Cosmopolitanism on Global Justice and Universal Fundamental Rights // Вестник Российского университета дружбы народов. Серия: Политология. 2020. Т. 22. № 3. С. 352-366. DOI: 10.22363/2313-1438-2020-22-3-352-366

\section{Introduction}

The paper seeks to answer the following question: What are the fundamental rights and duties to be implemented and enforced at the global level according to the main theories of global justice and how the conceptualization of a fair mean of fundamental rights can solve their limitations? 
The paper further develops the debate on global justice going beyond the mainstream theories on this topic, i.e. statism and cosmopolitanism (or globalism). Indeed, statism argues that concerns of justice apply only within the national borders failing to take into account the systemic nature of global politics while cosmopolitanism states that there are principles of justice applying at the global level lacking to take into account the (weak) feasibility of their cosmopolitan reforms.

The main goal of the paper is to overcome their limitations envisioning a conceptualization of social and political justice and fundamental rights, and corresponding duties, which is able to adapt to the thickening of the relations among peoples and persons while being sensible to the different contexts in which the claims of justice are framed.

To pursue this aim, this paper builds on the main findings of Forst's critical theory of social and political justice to sketch out a fair mean according to which the validity of claims of justice and the justifiability of the enforcement of the corresponding duties can be assessed including both theoretical studies - at the levels of public ethics and political theory - and empirical researches.

Its originality lies in the attempt to assess the fairness of the coercive norms establishing the global distribution of rights and duties, and thus of power, according to the level of arbitrariness in inequalities, the relevance of the object of the rights in question for a worthwhile life and the extent of the ground of justice. Taking all these elements into account, the further, and maybe the most relevant, challenge of the paper is to prove that rights, and above all categories of rights, ought always to be implemented in relation to one another and, thus, according to a common fair mean.

\section{Global justice and universal fundamental rights}

The object of this paper involves terms, among the others, (global) justice and rights, which are debated in several fields of study and whose conceptualization has been at the core of long-standing disputes which are widening more and more. That is the reason why it is essential to frame the discussion explaining how these notions are meant in this paper and how the analysis is developed. Thus, before delving into the main theories of global justice it is worth to make both terminological and methodological clarifications about the object of this paper. Even though it would be practically impossible to sketch out a universal shared conception of global justice and universal fundamental rights and duties, a wide agreement has been reached in the way they are outlined below.

In a first attempt to explain what justice is, it is possible to say that «Justice, at its core, concerns itself with who deserves what and why» [1] and it can be seen as the commitment to fighting against morally arbitrary inequalities [2]. Being slightly more precise, however losing neutrality getting a bit closer firstly to cosmopolitan conception and secondly to Rawlsian and statist conception of justice, justice can be defined as the fair distribution of fundamental benefits (e.g. claims, liberties, powers, and immunities) and burdens (e.g. duties and liabilities) to all [3] and can 
be retained «the first virtue of social institutions» [4]. It goes without saying that global justice regards the fairness of the above-mentioned distribution at the global level. To provide a first sketch on the standing of statism and cosmopolitanism on this topic, statism argues for the fact that the current global distribution is fair, or at least is not related to justice, and relieving the burdens of the worse off is a matter of humanitarian aid while cosmopolitanism states that principles of justice apply also at the global level considering the current global distribution unjust.

As already mentioned above, rights can be defined as fundamental benefits while duties as fundamental burdens. Looking at the core meaning of rights, to have a right means to have a valid claim [5] which entails (justifiable) duties to others. As also the author of one of the most sophisticated analysis of rights, Hohfeld, admits, «"in the strictest sense" all rights are claims» [6]. In a nutshell, duty is «that which one ought or ought not to do» [7]. Duties are obligations, or justified burdens, which persons or peoples ought to bear. Obviously, there are different categories of rights and duties, such as moral and legal ones, which we will touch upon further on. For the main purpose of this paper, however, the focal point to bear in mind is that each right has one or multiple corresponding duties, and each duty can be seen as a justifiable restriction of another right. Indeed, quoting again Hohfeld, "'Duty" and 'right' are correlative terms. When a right is invaded, a duty is violated» [7] and, for this, they can be seen as two sides of the same coin, i.e. justice.

The paper makes use of a critical methodology comparing the main points of the two leading theories on the above-mentioned topics and trying to go beyond them proposing another (balanced) approach to solve their drawbacks. Some fundamental remarks must be outlined on what the paper focuses and what has been left out in order to avoid losing the main aim of the work. Thus, the paper restricts the analysis of statism and cosmopolitanism concentrating on their conception of the scope of justice, i.e. the assessment of the extent to which the global context can be considered a context of justice and the rights and duties which persons and peoples ought to enjoy and ought to bear at the global level according to their paradigms. The paper does not deal with the universal foundation of both civil and political rights and, social and economic rights, so on defined as socio-economic rights, focusing on their dialectic relations and global justification, as well as on the justification of the corresponding duties they entail.

\section{Statism and the 'absolutization' of associative duties}

Before delving into the main points of statism it is necessary to underline that almost all the statist scholars do not deny the gruesome facts of inequality in world economy related to lack of democracy and unequal enjoyment of fundamental socioeconomic opportunities and basic liberties. This is a situation which is a «disaster from a more broadly humanitarian point of view» and, for this, «there is some minimal concern we owe to fellow human beings» [8]. Quoting the cosmopolitan scholar Thomas Pogge, the statist scholar Nagel underlines that «roughly 20 per cent of the world's population live on less than a dollar a day, and more than 45 per cent 
live on less than two dollars a day, whereas the 15 per cent who live in the highincome economies have an average per capita income of seventy-five dollars a day» [8] and even though the situation seems to be improving in absolute terms, global relative deprivation, strictly linked to the absolute deprivation, remains a serious global burden which can put in doubt the improvements in the fight against global inequalities defended by many Statists [8-10].

However, the main question we should focus on is if those global burdensome inequalities in socio-economic opportunities and fundamental liberties make rise any justifiable demand for justice. In other words, what is necessary to understand is the potential and practical applicability of standards of justice at the global level. According to statism - and this paper refers mainly to the most relevant exponents of this theory, i.e. Thomas Nagel and David Miller - egalitarian distributive norms can apply only among citizens of a common state according to the «associative duties» that citizens owe one another in virtue of their membership to the same national community. Accordingly, concerns of justice apply only within national borders since, for statists, the primary context of justice is the national one and the political communities (peoples) organized into states are the primary focus of global justice [11]. Global justice can be understood only in terms of principles of justice which regulate the relations among states but not the relations among persons belonging to different states since «the moral units of the order are peoples, not individuals, and the values have to do with the relations among these collective units rather than relations of individuals across the world» [8].

As one of the preeminent representatives of the realist school and the Hobbesian (political) understanding of justice, Nagel argues for the fact that no standards of social justice can hold at the global level and that only states are relevant agents of justice in the global arena. According to Nagel, «even if justice is taken to include not only collective self-interest but also the elimination of morally arbitrary inequalities, or protection of rights to liberty, the existence of a just order still depends on consistent patterns of conduct and persisting institutions that have a pervasive effect on the shape of people's lives» [8]. Even though Nagel recognizes the fundamental commitment of justice to fighting against morally arbitrary inequalities, he does not accept the possibility to understand the global context as a context of justice: the reason is that for how morally motivated can be the individual demands for global justice they cannot have practical expression. Besides, he compares two conceptions of justice, the cosmopolitan, or moral conception, which we take apart for a while delving into it further on, and a second conception which Nagel defines 'political conception' of justice according to which «justice should be understood as a specifically political value, rather than being derived from a comprehensive moral system, so that it is essentially a virtue - the first virtue - of social institutions» [8]. Not only does this conception empty justice of its inner moral dimension, but Nagel states that he opts for the political conception of justice, rather than the cosmopolitan one, because «the political conception is accepted by most people in the privileged nations of the world, so that, true or false, it will have 
a significant role in determining what happens» without, however, justifying the reasons for this choice. This weakens his defence of the political conception of justice insofar as he justifies this decision by the fact that it is preferred by the majority of people taking as given that the most shared option is the fairest one. In any case, even if Nagel categorically excludes that global morally arbitrary inequalities can entail demands of justice, he states that they are a matter of humanitarian assistance since «the most basic rights and duties are universal, and not contingent on specific institutional relations between people» [8]. Moreover, he makes a distinction between negative rights, such as bodily inviolability, freedom of expression and freedom of religion, and positive rights, such as right to democracy, equal citizenship, non-discrimination, equality of opportunity and the amelioration through public policy of unfairness in the distribution of social and economic goods [8] arguing for a priority of the first category over the latter one, insofar as negative rights «set universal and prepolitical limits to the legitimate use of power, independent of special forms of association». Indeed, «it is wrong for any individual or group to deny such rights to any other individual or group» while socio-economic justice is fully associative since «it depends on positive rights that we do not have against all other persons or groups, right that arise only because we are joined together with certain others in a political society under strong centralized control» [8]. Therefore, according to Nagel and more broadly to many statists, the scope of negative rights, in which the category of civil and political rights, is wider than the scope of positive rights can be included, in which the category of socio-economic rights can be included. This can be explained by the common supposition that negative rights imply less burdensome duties, i.e. duty not to do, than positive rights which implies more demanding duties, i.e. duty to do. Even though one of the aims of the paper is to overcome this supposition, this task will be addressed in the final part of the work. For now, it is just relevant to understand this focal difference and the statist position on this matter.

As another leading scholar of statism, Miller frames the discussion on the justification of the distribution of rights and duties debating the difference between ethical particularism and ethical universalism [12] defending the first insofar as the special relationships citizens have one another motivate them to pursue justice. Without going excessively deep into his argumentation, and maintaining the focus on the main topic of the paper, the most interesting point of Miller's theory of global justice is his defence of the ethics of nationality and the global minimum of human right to be set at the global level. Miller maintains that we have special obligations to compatriots which we do not owe to other human beings and global justice ought to be understood not in terms of equality, but in terms of basic human rights that belong to human beings everywhere and which can entail remedial responsibility on outsiders [13]. Thus, Millers admits that we owe some responsibilities toward the world's poor but of a kind that protection of universal socio-economic rights can only be a matter of sufficiency and not equality, and, more important, a matter of humanitarianism rather than justice, strictly speaking. 
Besides lacking to recognize the proper relevance of the moral dimension of the concept of justice, statist theory seems to be excessively stuck in the status quo without being able to adapt to the fast changes in persons' and peoples' global relations. Indeed, its ideas fail to take into account the global level as an increasingly relevant context of justice, that is according to the thickening of global interconnection and interdependence. Moreover, statists, on the one hand, gives much relevance to the rights to liberty among collective agents, as states, without however properly taking into consideration the rights of individuals at the global level and, on the other hand, absolutizes the 'associative duties' as the only category of duty which can rise demands of justice and which, thus, justifies their restricted scope at the global level.

\section{Cosmopolitanism and the chimera of a full-fledged global justice}

Cosmopolitans (or globalists) position themselves in a standing diametrically opposite to statists. As statists, cosmopolitans denounce the grave burdensome of global inequalities in socio-economic opportunities and fundamental liberties arguing for the fact that a plan to end severe poverty for over 2.5 billion human beings whose aggregate shortfall amounts to barely $\$ 300$ billion annually which are well under the 1 per cent of the aggregate annual gross national incomes of the highincome economies - could be carried out through reforms which would entail a negligible reduction in the standard of living for the 1 billion people living in the high-income countries [3]. However, not only do cosmopolitans argue for the negligible sacrifice that the relief of the worse-off would entail but, more importantly, they underline that this fact is a matter of justice insofar as global unfair inequalities are replicated by the global order which ought, for this, to be retained unjust.

Cosmopolitanism is founded on the idea that all human beings, regardless of their political affiliation, are (or can and should be) citizens in a single community basing on universal moral norms [14]. According to cosmopolitanism, principles of justice regulating the fair distribution of rights and duties hold also at the global level and global justice should be conceived in terms of an institutional cosmopolitanism based on universal human rights [3] which leads to assess the global order as unjust insofar as it is unable to globally ensure the overall protection of fundamental rights. Cosmopolitanism develops in the framework of the broad philosophical argument of moral universalism ${ }^{1}$ which maintains that some ideas have universal power, i.e. there are universal principles which apply to the whole humanity.

\footnotetext{
${ }^{1}$ According to Pogge, «a moral conception, such as a conception of social justice, can be said to be universalistic if and only if A) it subjects all persons to the same system of fundamental moral principles; B) these principles assign the same fundamental moral benefits (e.g. claims, liberties, powers, and immunities) and burdens (e.g. duties and liabilities) to all; and C) these fundamental moral benefits and burdens are formulated in general terms as not to privilege or disadvantage certain persons or groups arbitrarily» [3, p. 98].
} 
According to one of the leading exponents of cosmopolitanism, Thomas Pogge, there are three specific features which are shared by almost all the diverging strands of cosmopolitanism: Individualism: the ultimate units of concern are individual human beings or persons rather than other categories of agents, like collective ones which can be units of concern only indirectly, in virtue of the participation of their members; universality: the status of ultimate unit of concern attaches to every living human being equally; and generality: this special status has global force, which is to say that persons are ultimate units of concern for everyone [3]. Therefore, cosmopolitanism maintains that persons are the primary focus of justice and the global context ought to be considered as the primary context of justice since persons are, first and foremost, members of a single universal community. States can only be secondary or indirect units of concern since they are subordinated to the most relevant units of concern, i.e. persons.

Since there are many different categories of cosmopolitanism, such as moral, political, legal, institutional, economic, the debate will be restricted on the work of an author, Thomas Pogge, which seeks to bridge these different conceptions of cosmopolitanism remaining however closer to the moral one, which can be considered the most characteristic of this theory of global justice. As a matter of fact, he argues for the combination of two compatible conceptions of moral cosmopolitanism: interactional moral cosmopolitanism and institutional moral cosmopolitanism. According to this distinction, the first one formulates fundamental principles of ethics that assign responsibilities for the implementation of universal basic rights directly to persons and groups, whereas the second one postulates fundamental principles of social justice that assign these responsibilities to the institutional scheme [3]. However, developing a variant of institutional cosmopolitanism - precisely one which makes persons and peoples bearing responsibility for the support to a global unjust order which authorizes and enforces unfair inequalities in violation of a general negative duty - Pogge maintains that only the institutional conception of cosmopolitanism can be retained a matter of social justice while the interactional conception, still not irrelevant to reduce global unfair inequalities, remains a question of individual ethics.

Placing the question of how universal rights ought to be conceived, Pogge argues for a validity of moral human rights which is independent of any social order - which however plays a crucial role for their realization - an idea which has been widely and progressively acknowledged since the aftermath of the World War II [3]. Moreover, Pogge considers moral and legal rights not in contrast to each other but rather claims that the first category pre-exists the second (whose instrumental role for the realization and adjudication of moral rights is, in any case, a matter of fact). Indeed, the relation between moral and legal rights is conceived in such a way that avoids any conceptual connection between these two terms. Moral rights are moral claims which are valid ${ }^{2}$ regardless of their actual legal

\footnotetext{
${ }^{2}$ In Pogge, the validity of these moral claims is explained in the light of the consensus which their enunciation in the UDHR as human rights has obtained. Accordingly, Pogge seems to leave pending
} 
recognition and judicial adjudication and, thus, their juridification ought not to be understood as demanding. Pogge does not underestimate the relevance of legal rights for the implementation of (moral) human rights but he argues that such legal rights need not to have the same content of moral human rights and highlights that secure access to the object of moral rights - that is what really matters - may be maintained also in other ways [3]. It follows that legal rights are effective, and probably the strongest, means to realize moral rights however other tools, as nonlegal practices and commitment by the citizenry, can be considered in their own way important to pursue this aim. Pogge argues for the inclusion of the corresponding legal right of a moral right in the law or constitution when its juridification is required to ensure the secure access to its object - as it is, for example, for the right to vote [3]. In his work, he also poses the main focus on a specific category of rights, i.e. socio-economic rights, underlying how they are «currently, and by far, the most frequently unfulfilled human rights» [3] arguing for the fact that this underfulfillment also plays a major role in explaining global deficits in the protection of civil and political human rights. However, his major focus on socio-economic rights, and issues as world poverty, unequal distribution of wealth, inequalities in the standard of living seems to underestimate the relevance of civil and political rights.

One of the main criticisms to cosmopolitan ideas is that cosmopolitanism almost completely discharges justice from its not irrelevant political weight. In the wake of this observation, other limitations of this theory are the deficiency of cosmopolitanism to not take into account the relevance of special duties linked to particular relations among persons, such as those related to the shared national identity, as well the weak practical feasibility of the reforms cosmopolitans propose in order to realize the utopian world they conceive.

\section{Universal fundamental rights as a fair mean}

Before proceeding with the explanation of the 'middle road' which can cope with the main limitations of statism and cosmopolitanism it is worth to spend a few more words on one of the core concepts which is debated in this paper, i.e. the concept of justice, and which, when first appeared in the Ancient Greek, it immediately triggered wide theoretical controversies.

In Plato's work The Republic, in which an early theory of justice was set out, Thrasymachus challenges Socrates arguing that justice is «simply the interest of the stronger» [15], i.e. merely whatever the more powerful say it is [16]. Yet, without admitting that a reasonable conceptualization of justice is possible outside the mere will of the stronger, it would make no sense to speak about different perspectives on social justice since the intersubjective relations, above all at the global level, would be left to the state of homo homini lupus (which is not so distant from the current

the foundational question of universal rights and the concept of rights itself. Differently, Forst seeks to explain the validity of moral rights according to their moral and political construction on the very basic moral right (and duty) to reciprocal and universal justification. 
scenario of the global agents' relations). Indeed, the question of power is the first question of justice because justice should not only focus on «the distribution of goods, but on the justice of the 'basic structure' of relations of political and economic power, that is, relations of government, of production, and of distribution» [16]. In this sense, justice is related to power but is specifically conceived to contrast the arbitrary asymmetries of power inequalities, that is, opposing Thrasymachus, precisely avoiding justice to be what the stronger wants it to be.

In the same vein of Plato's reasoning, and at odds with Thrasymachus, Forst opts for a constructivist answer to the question of the 'firm ground' of justice, which, in this sense, is posed anew. Not only does Forst argue that «there is a reasonable justification for a conception of justice, but also that it goes back to a single root - that is, that the various aspects of justice in social and political contexts, and even beyond national borders, ultimately refer to a normative core: the one basic human right to justification» [16]. This basic right to reciprocal and general justification is conceived in such a way that it is reasonably shareable by the whole humanity and Forst explains its main criteria as follows:

Reciprocity means that no one may refuse the particular demands of others that one raises for oneself (reciprocity of content), and that no one may simply assume that others have the same values and interests as oneself or make recourse to "higher truths" that are not shared (reciprocity of reasons). Generality means that reasons for generally valid basic norms must be sharable by all those affected. Principles and norms can claim to be valid only if they can be agreed to reciprocally (without demanding more from others than one is also willing to concede, and without projecting one's own interests and convictions on others) and generally (without excluding anyone concerned and their needs and interests), that is, those principles and norms that... no one can "reasonably" reject [16].

Therefore, only those norms and actions which are reciprocally and generally justifiable can be retained just and valid so long as they avoid the reasons of some persons to prevail to those of others and include the reasons of all those affected. Moreover, what is important to understand is that reasons of persons are equally worth to be heard and equally count in shaping social institutions insofar as they respect the reciprocity and generality criteria which, so, serve as a filter for claims and reasons that can be "reasonably rejected". That is, reciprocity and generality are appropriate principles to apply to intersubjective interactions, and for the justification of the rules governing them, because not only do they help to provide everyone with the possibility to participate in shaping the rules of justice, and thus the distribution of duties (burdens) and rights (benefits), in an equal position, but they also make it possible to distinguish between more or less justifiable arguments and to evaluate the 'reasonableness' of positions and claims when there is dissent [16]. Thus, the right (and the corresponding duty) to justification - in this sense, the core essence of social and political justice - is shaped by these two criteria insofar as one cannot make him/her reasons and claims prevail on those of the others through the means of arbitrariness and domination and argue for exclusion of persons affected, along with their needs and concerns, as well as avoid to abide themselves by norms reasonably widely shared or shareable and which they would raise for themselves. 
In the attempt to bridge Forst's right to justification and the Aristotelian fair mean, which will be recalled further on, the Aristotelian conceptualization of justice, mainly related to the distribution of honours and benefits according to the merits $^{3}$, must be explained. The Aristotelian account of justice will provide the basis to investigate how different categories of rights, precisely socio-economic and civil and political ones, and the corresponding duties, are related. Hence, the purpose here is not to provide a comprehensive understanding of Aristotelian conception of justice, but rather to give a first and, of course, not exhaustive, sketch on what distributive justice refers to in order to strive for a justification of a 'fair mean' which consists of fundamental civil and political and socio-economic rights and which can help to conceive a measure according to which these rights ought to be implemented:

Justice is a kind of mean, but not in the same way as the other virtues, but because it relates to an intermediate amount, while injustice relates to the extremes. And justice is that in virtue of which the just man is said to be a doer, by choice, of that which is just, and one who will distribute either between himself and another or between two others not so as to give more of what is desirable to himself and less to his neighbour (and conversely with what is harmful), but so as to give what is equal in accordance with proportion; and similarly in distributing between two other persons. Injustice on the other hand is similarly related to the unjust, which is excess and defect, contrary to proportion, of the useful or hurtful. For which reason injustice is excess and defect, viz. because it is productive of excess and defect-in one's own case excess of what is in its own nature useful and defect of what is hurtful, while in the case of others it is as a whole like what it is in one's own case, but proportion may be violated in either direction. In the unjust act to have too little is to be unjustly treated; to have too much is to act unjustly [17].

Basically, Aristotle defines justice as consisting of what is lawful and fair. Keeping aside the understanding of justice as law-abiding, its second aspect, here taken into consideration, implies two main elements: equitable distribution and correction of the excess. These principles may be conceived as valid both for individuals and things, that is in the fairness of relations among individuals and distributed things. Therefore, according to Aristotle, justice is not merely a matter of everyone getting the same fixed amount of something but rather obtaining or giving what one respectively does or does not deserve. In order to evaluate the right proportion, a metric is required, which, in turn, needs a scale of values. Taking as example the distribution of freedoms and socio-economic opportunities as the things to be fairly distributed ceteris paribus, the full equality of freedom for everyone to enjoy her own private property without any taxation admissible would be an injustice insofar as it would let wealthy people have many more, to some

\footnotetext{
${ }^{3}$ «And the same equality will exist between the persons and between the things concerned; for as the latter the things concerned-are related, so are the former; if they are not equal, they will not have what is equal, but this is the origin of quarrels and complaints-when either equals have and are awarded unequal shares, or unequals equal shares. Further, this is plain from the fact that awards should be 'according to merit'; for all men agree that what is just in distribution must be according to merit in some sense, though they do not all specify the same sort of merit, but democrats identify it with the status of freeman, supporters of oligarchy with wealth (or with noble birth), and supporters of aristocracy with excellence». [17, p. 79].
} 
extent undeserved, socio-economic benefits than poor people. But, also, the opposite case ought to be considered unjust, that is strict equality of socio-economic opportunities depriving everyone of everything making it available to all would not be just insofar as it would strongly disregard equal distribution of freedoms. Rather progressive taxation which entails higher tax for the better off and low tax for the worse off to properly compensate the difference in socio-economic opportunities may be conceived as just since it is a substantial kind of a (fair) mean. Still, the determination of the proportionally equal distribution and the correction of excesses and defects are related to the relevance of the things distributed and the metrics according to which to evaluate the just mean. Thus, what is the fair mean universally justifiable and reasonably shareable by all is an open question, on which the following reasoning seeks to shed light.

The above-mentioned example refers to the potential conflict between the fulfillment of the right to private property, through the recognition and protection of the freedom to enjoy their own private property, vis-à-vis the fulfillment of socioeconomic rights, through equal distribution of socio-economic opportunities which require some sort of taxation. The above-mentioned progressive taxation may be a policy pursuing that kind of mean to which Aristotle refers and according to which the balance between the fulfillment of different (sometimes contrasting) rights can be established. Investigating deeply and in detail this intermediate amount is something which would go beyond the aim of this paper, but some reflexions on it can be outlined taking into consideration other relevant elements of Forst's conception of justice.

Combining the Aristotelian understanding of justice with the critical theory of political and social justice and the moral constructivist conception of human rights of Rainer Forst it is possible to sketch out a formal and substantial account of the fair mean which is morally and politically constructed on the really basic rights to justification. Not only does this really basic right help to justify concrete rights ${ }^{4}$ but it is also useful - and this is what is of interest for this paper - to justify the implementation of interrelated different rights and the corresponding duties they bear by establishing which right has priority to be better fulfilled in case of conflict among different rights. Recognizing the main commitment of justice to fighting against arbitrariness and the need of a context of justice, i.e. a context of political and/or social relations of cooperation as well as conflict, in order to make the concept of social of justice meaningfully applicable [18], it is relevant to note how the conception of justice we are trying to sketch out in this paper is able to take together its moral and political aspects. Understanding the fair mean as consisting in all those reciprocally and generally justifiable fundamental rights and, accordingly, all those reciprocally and generally justifiable fundamental duties

\footnotetext{
${ }^{4}$ «It is appropriate to call the right to justification (a) a moral right and (b) the (most) basic right; for by itself it is not a specific, intersubjectively established and recognized human rights, but rather the basis of the justification of concrete rights». [16, p. 210].
} 
which these rights entail, the measure of the justifiability of these fundamental rights and duties can be assessed in relation to the level of arbitrariness and domination the claimant suffers, that is, the moral aspect of justice, along with the extent of the context in which the demand ought to be framed, that is, the political aspect of justice. In an attempt to concretely define what precisely this fair mean consists of, we may say that it corresponds to basic freedoms and fundamental socio-economic opportunities which everyone would consider essential for a worthwhile life and which represent the basic fundamental common objects of civil and political rights and socio-economic rights.

Therefore, the main originality of the paper lies on the reconsideration of civil and political and socio-economic rights, thus, of fundamental rights in general, according to the level of arbitrariness suffered by the claimant and the extent of the context of justice in which to frame the claim along with the relevance of the enjoyment of the object of the right for a worthwhile life and the reasonable justification of the duties the counterpart ought to bear. As a consequence, it is necessary to admit the relativeness of the overall enjoyment of different universal fundamental rights. Indeed, one of the innovative points this paper seeks to unfold corresponds to a new approach, which can be defined as a balanced approach, toward rights which understands universal fundamental rights relative in scope. Accepting the universality of different categories of fundamental rights, it is impossible to deny that an absolute fulfillment of all of them is a chimera ${ }^{5}$. The main issue at stake here is that no system of rights can avoid potential conflicts rising in the attempt to fulfill different fundamental rights due to the inner interrelation among them ${ }^{6}$. Denying the inner interrelation among different rights would be equal to embracing a fundamentalism of rights which may turn into a disproportionate fulfillment of some rights at the expense of the lack of secure access to the basic object of some others. Accordingly, the proposal outlined in this paper is a balanced and proportionate fulfillment of rights in accordance with their core object, which may potentially represent the Aristotelian fair mean. That is to say that the best overall enjoyment of rights can be ensured by admitting that rights can only be fulfilled to some extent since intrinsically related one to another. Thus, this weighted fulfilment of rights ought to be conceived related to the basic object

\footnotetext{
${ }^{5}$ Even the absolute fulfillment of one right may be retained a chimaera [3, p. 180].

${ }^{6}$ If the potential conflict rising among rights must not be denied, there is necessary to not incur into the opposite mistake, i.e. the potential mutual reinforcing of different rights: Landman T. The Scope of Human Rights: From Background Concepts to Indicators. Essex: Human Rights Center; 2005; p. 6. For a conception of rights as indivisible and mutually reinforcing see World Conference on Human Rights, Vienna Declaration and Programme of Action, Vienna: OHCHR; 1993; Boyle K. Stock-taking on Human Rights: The World Conference on Human Rights, Vienna 1993. Political Studies. 1995; 43 (1): 79-95; Donnelly J. The Social Construction of International Human Rights. In: Dunne T., Wheeler N.J. Human Rights in Global Politics, Cambridge: Cambridge University Press; 1999. For a theory of relative universality of human rights see: Donnelly J. The Relative Universality of Human Rights. Human Rights Quarterly. The Johns Hopkins University Press; 2007; 29 (2): 281-306.
} 
of a right and the justification of the corresponding duties, avoiding that an (over)fulfillment of a right would permit other rights to be left excessively behind.

\section{Conclusion}

The question of global justice, and more specifically the problem of the fair global distribution of rights and duties among peoples and persons, is catching more and more attention not only in the academia but also in politics and economics, even though with different connotations. Already more than two centuries ago, Immanuel Kant underlined that «the intercourse, more or less close, which has been everywhere steadily increasing between the nations of the earth, has now extended so enormously that a violation of right in one part of the world is felt all over it» $[19 ; 20]$. At that time as even much more as now, the rising global interconnection and interdependence created a kind of universal common feeling that a violation of a right in a part of the world was perceived by all the inhabitants of the world. However, as we have seen in this paper, there are many issues regarding how to globally ensure peoples and persons secure access to the basic object of fundamental rights.

The innovative approach, that we called balanced approach, toward global justice and fundamental universal rights and duties, only broadly sketched out in this paper, can be of help for a better understanding of the relations among different categories of rights at the global level and to clarify the extent to which the global context is becoming a relevant context of justice. This account of global justice is founded on a justifiable fair mean consisting in fundamental universal rights and duties and which takes into consideration the existence of concrete political and social relations of cooperation as well as conflict for assessing the meaningful applicability of demands of justice. This account of global justice may represent a potential solution for the tension between political and moral conceptions of justice framing the justifiable request for justice at the proper and reasonable level and being able to adapt itself to the transformation of the different contexts of justice.

\section{References}

[1] Waters R., Scheinpflug C. International Relations theory. Social Science Libre Texts, E-International Relations; 2017.

[2] Giovanola B., editor. Public ethics, social justice, inequalities. Roma: Carocci; 2016. (In Ital.).

[3] Pogge T. World Poverty and Human Rights, Cosmopolitan Responsibilities and Reforms. 2nd ed. Cambridge: Polity press; 2008.

[4] Rawls J. A Theory of Justice. Cambridge: Harvard University Press; 1971.

[5] Feinberg J. The Nature and Value of Rights. Journal of Value Inquiry. 1970. 4: 243-257.

[6] Hohfeld W.N. Fundamental Legal Conceptions. W. Cook, editor. New Haven: Yale University Press; 1919.

[7] Hohfeld W.N. Some fundamental legal conceptions as applied in judicial reasoning. Yale Law Journal. 1913; 23 (1), 16-59.

[8] Nagel T. The problem of Global Justice. Philosophy \& Public Affairs. 2005; 33 (2): 113-147.

[9] Oxfam international. Reward work, not wealth. London: Oxfam GB; 2018.

[10] Ypi L. Global Justice and Avant-Garde Political Agency. Oxford: Oxford University Press; 2012. 
[11] Kleingeld P., Brown E. Cosmopolitanism. The Stanford Encyclopedia of Philosophy. Zalta E.N., editor. Stanford University: Metaphysics Research Lab; 2019.

[12] Miller D. On Nationality. Oxford: Clarendon Press; 1992.

[13] Miller D. National Responsibility and Global Justice. Oxford: Oxford University Press, 2007.

[14] Mikalsen K.K. No cosmopolitan morality without state sovereignty. Philosophy and Social Criticism. 2017; 43 (10): 1072-1094.

[15] Plato. Republic. 380 B.C. Davies J.L., Vaughan D.J., translators. Ware: Wordsworth Editions Limited; 1997.

[16] Forst R. The Right to Justification: Elements of a Constructivist Theory of Justice. Jeffrey F., translator. New York: Columbia University Press; 2012.

[17] Aristotle. Nichomachean Ethics. 350 B.C. Ross WD, translator. Kitchener: Batoche Books; 1999.

[18] Forst R. Context of Justice: Political Philosophy Beyond Liberalism and Communitarians. Farrell J.M.M., translator, Berkeley: University of California Press; 2002.

[19] Landman T. The Scope of Human Rights: From Background Concepts to Indicators. Essex: Human Rights Center; 2005. p. 6.

[20] Boyle K., Stock-taking on Human Rights: The World Conference on Human Rights, Vienna 1993. Political Studies. 1995; 43 (1): 79-95.

[21] Donnelly J. The Social Construction of International Human Rights in Dunne T., Wheeler N.J. Human Rights in Global Politics, Cambridge: Cambridge University Press; 1999.

[22] Donnelly J. The Relative Universality of Human Rights. Human Rights Quarterly. The Johns Hopkins University Press. 2007; 29 (2): 281-306.

[23] Kant I. Zum ewigen Frieden. Ein philosophischer Entwurf. Konigsberg: Nicolovius F., 1795, en. tr.: Perpetual peace: A philosophical Sketch. Ritchie L, editor. London: Unwin Brothers; 1903. (in En.).

[24] Kleingeld P. Kant's Cosmopolitan Law: World Citizenship for a Global Order. Kantian Review. Cambridge University Press. 1998; 2: 72-90.

\section{Information about the author:}

Fabio Coacci - postgraduate Diploma of Giacomo Leopardi School of Advanced Studies of the University of Macerata, Lecturer and PhD Student of MGIMO University, Assistant Lecturer and PhD Student of University of Macerata (Italy) (ORCID ID: 0000-0002-4504-6067) (f.coacci1 @ studenti.unimc.it).

\section{Информация об авторе:}

Коаччи Ф. - аспирант и дипломант Высшей школы им. Джакомо Леопарди Университета Мачераты, аспирант Московского государственного института международных отношений (университета) (МГИМО) МИД РФ (ОRCID ID: 0000-0002-4504-6067) (f.coacci1 @ studenti.unimc.it). 